\title{
STUDY OF HEAT TREATMENT EFFECT ON STRUCTURE AND SOLUBILITY OF CHITOSAN FILMS
}

\author{
Tetyana Solodovnik $^{1, *}$, Hennadiy Stolyarenko ${ }^{1}$, Andrii Slis ${ }^{1}$, Valentyna Kultenko ${ }^{1}$
}

https://doi.org/10.23939/chcht11.02.175

\begin{abstract}
Chitosan films were obtained in the salt form and in the hydroxide form. Films were prepared by dry method of forming. For the production of films chitosan from mycelium biomass waste of fungus Aspergillus Niger was used. The effect of heat treatment on the structure and solubility of chitosan films was studied. It was established that during the heat treatment of the films the process of amidation takes place, which in turn leads to the structure ordering and reduces the solubility of the films.
\end{abstract}

Keywords: thermal modification, chitosan, film, solubility, swelling.

\section{Introduction}

Chitosan is a linear polysaccharide of (1-4)-linked 2-amino-2-deoxy-beta-D-glucopyranose (D-glucosamine, $\mathrm{GlcN}$ ). Chitosan is obtained from natural polysaccharide chitin, which consists of (1-4)-linked 2-acetamido-2deoxy-beta-D-glucopyranose $\quad(N$-acetylglucosamine, GlcNAc). The reaction of deacetylation is used to produce chitosan from chitin (Fig. 1).

Chitin acetylamide groups $\left(-\mathrm{NH}-\mathrm{C}(\mathrm{O})-\mathrm{CH}_{3}\right)$ are converted into amine groups $\left(-\mathrm{NH}_{2}\right)$ of chitosan under high temperature (353-403 K) and concentrated solution of alkali (30-40\%) [1]. The total order structure of the polymer is markedly reduced in the process of obtaining chitosan from chitin. Chitosan can bind hydrogen ions and acquire excess positive charge due to the presence of free amino groups in its chain [2]. Furthermore, free amino groups determine chelating properties of chitosan and its ability to form complexes with heavy metal ions, radioactive isotopes and toxic elements. Owing to this chitosan interacts with substances of different origin by persistent chemical and electrostatic bonds. Chitosan can bind soluble organic substances, fats and oils due to the large number of hydrogen bonds. Thus, chitosan can be

\footnotetext{
${ }^{1}$ Cherkassy State Technological University,

460, Shevchenko Blvd., 18006 Cherkassy, Ukraine

*soltav@ukr.net

(C) Solodovnik T., Stolyarenko H., Slis A., Kultenko V., 2017
}

described as a universal sorbent for removing impurities from aqueous solutions of organic substances and inorganic origin [3].

Chitosan can be described as a fibrous polymer. Chitosan is widely used for producing films, membranes, and fibers in various industries [4-7]. Many scientists proved that chitosan can be used as a raw material for the production of ion-exchange membranes and films [8-10]. It is known that the properties of chitosan films depend on the morphological structure of the polymer, its molecular weight, the number of free amino groups, the nature of chitosan, the method of film formation, and the type of solvent used to prepare chitosan solutions [11-16]. However, it is known that chitosan films are characterized by unstable properties and solubility in acidic solutions. Therefore, scientists from different countries are working on the problem of stabilizing the physical and chemical properties of chitosan films and reduction of their solubility [17-24].

The aim of our work was to study the effect of temperature and conditions of formation on the structure, solubility and swelling degree of chitosan films.

\section{Experimental}

The percentage of GlcN-fragments in the structure of chitosan represents the degree of deacetylation (DD). Chitosan with degree of deacetylation $87 \%$ was used as a raw material for making films. Chitosan has been previously obtained from waste biomass of mycelium fungus Aspergillus Niger as described in [25]. Chitosan films in salt form (S-form) were prepared by dry forming. Films were formed from the initial $2 \%$ chitosan solution in $2 \%$ aqueous solution of acetic acid according to the method [26]. The solution was stirred by a magnetic stirrer for $15 \mathrm{~min}$.

Chitosan films (S-form) were used for the production of the films in hydroxide form (H-form). For this film S-form was treated with $2 \%$ sodium hydroxide solution for $2 \mathrm{~min}[27,28]$. Preparation of chitosan film (Sform) takes place according to the scheme (Fig. 2). Solvent anions $\left(\mathrm{CH}_{3} \mathrm{COO}^{-}\right)$are linked with amino groups of chitosan and they can react with alkali solution $(\mathrm{NaOH})$. 


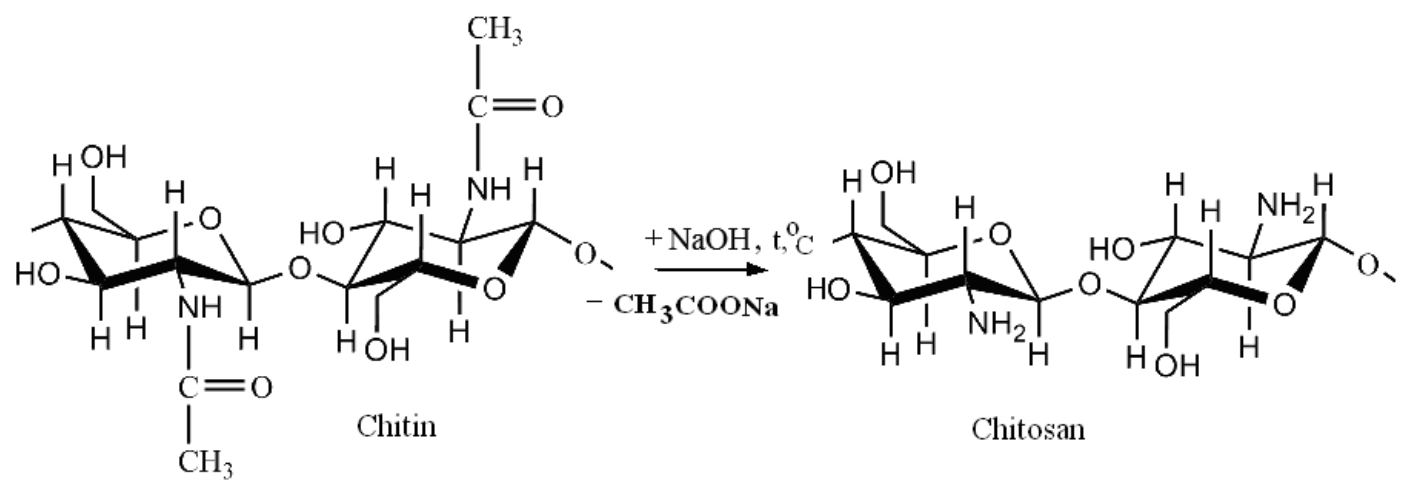

Fig. 1. The reaction of deacetylation

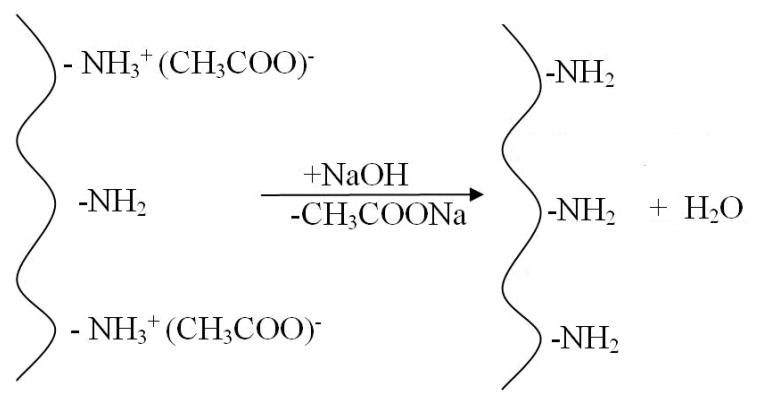

Fig. 2. Scheme conversions of S-form into H-form

The number of amino groups in chitosan films was determined by potentiometric titration according to the method [29]. We used a combined glass electrode in this method. $\mathrm{pH}$ was measured with the accuracy of \pm 0.01 . The electrode was tested by standard buffer solutions $(\mathrm{pH}$ $=1.1 ; 4.01 ; 6.86$ and 9.18). The nitrogen content in the amine and acetylamide groups of the chitosan films was determined as follows: $0.1 \mathrm{~g}$ of the film sample (accuracy of $0.0001 \mathrm{~g}$ ) was dissolved in $5 \mathrm{~cm}^{3}$ of $0.1 \mathrm{M}$ solution of hydrochloric acid. Dissolution was performed for one hour under constant stirring. After this $5 \mathrm{ml}$ of distilled water was added to this solution, stirred thoroughly and titrated with $0.1 \mathrm{M} \mathrm{NaOH}$ solution under constant stirring (291-293 K). Titration curve was constructed in the coordinates $\mathrm{pH}-V(\mathrm{NaOH})$. The volume of $\mathrm{NaOH}$ used in the titration was determined graphically from a titration curve. The nitrogen content $(W(\mathrm{~N})$, mass \%) in the amine and acetylamide groups of the chitosan films was calculated by the formula:

$$
W(N), \text { mas. } \%=\frac{\Delta V(\mathrm{NaOH}) \cdot c(\mathrm{NaOH}) \cdot 14}{1000 \cdot m} \cdot 100
$$

where $\Delta V(\mathrm{NaOH})$ - the volume of $\mathrm{NaOH}$ which was used in the titration; $c(\mathrm{NaOH})$ - the molar concentration of $\mathrm{NaOH}, \mathrm{mol} / \mathrm{l} ; m$ - the weight of chitosan film, g; 14 - the atomic weight of nitrogen, $\mathrm{g} / \mathrm{mol}$.
Mass fraction of deacetylated units $(\mathrm{GlcN})$ was calculated by the formula:

$$
\varphi_{N H_{2}}=\frac{W(N) \cdot 203}{14 \cdot 100 \%+42 \cdot W(N)}
$$

where $W(N)$ - the nitrogen content, mass \%; 161 - molar mass of the GlcN, g/mol; 14 - the atomic weight of nitrogen, $\mathrm{g} / \mathrm{mol}$.

Mass fraction of acetylated units (GlcNAc) was calculated by the formula:

$$
\varphi_{\mathrm{NHCOCH}_{3}}=\Delta \varphi_{\mathrm{NH}_{2}}+0.16
$$

where $\Delta \varphi_{\mathrm{NH}_{2}}$ - the difference between the mass fraction of deacetylated units in the baseline chitosan and after reaction of amidation; 0.16 - the mass fraction of acetylated units in the baseline chitosan.

The degree of conversion of deacetylated units to the acetylated units $\left(D C_{\mathrm{NH}_{2}}\right)$ was calculated by the formula:

$$
D C_{N H_{2}}=\frac{\Delta \varphi_{\mathrm{NH}_{2}}}{0.84}
$$

where $\Delta \varphi_{\mathrm{NH}_{2}}$ - the difference between the mass fraction of deacetylated units in the baseline chitosan and after reaction of amidation; 0.84 - the mass fraction of acetylated units in the baseline chitosan. 
Samples of chitosan films were dried for 10-72 h, the temperature range was $293-318 \mathrm{~K}$. Thermal modification was performed by heating the films at $388 \mathrm{~K}$ for $3 \mathrm{~h}$. Chitosan films in salt and hydroxide form (S-form- $\mathrm{T}$ and $\mathrm{H}$-form- $\mathrm{T}$ ) were obtained after a heat treatment.

The kinetics of swelling of the chitosan films were investigated by gravimetric analysis in buffer solutions with $\mathrm{pH}: 1.1 ; 5.5$ and 6.86 . Samples of chitosan films by weight of $0.01 \pm 0.003 \mathrm{~g}$ were used for analysis. The mass of the samples was determined on an analytical balance. The kinetics of swelling was observed between 1 and $60 \mathrm{~min}$. The degree of swelling of the films $(\alpha)$ was calculated using the formula:

$$
\alpha=\frac{m-m_{0}}{m_{0}} \cdot 100 \%
$$

where $m_{0}$ - the weight of chitosan film before swelling, $\mathrm{g}$; $m$ - the weight of chitosan film after swelling, g.

Kinetic curves were constructed in the coordinates: the degree of chitosan films swelling - time of swelling. The equilibrium value of the degree of swelling $\left(\alpha_{e q}\right)$ was calculated using the kinetic curves. The solubility of chitosan films was determined by the gravimetric method [30].

The films of chitosan in S-form and $\mathrm{H}$-form were analyzed using IR spectroscopy (Specord IR-75). The samples of chitosan films were ground into small pieces prior to pressing into tablets with $\mathrm{KBr}$ powder with a ratio of about 2:100. The IR spectra were recoreded in the wave number ranges of $400-4000 \mathrm{~cm}^{-1}$ with $32 \mathrm{scan}$ at $4 \mathrm{~cm}^{-1}$ resolution. Spectra were explained using the MicroCAL Origin v.6.10 program.

\section{Results and Discussion}

Table 1 shows the experimental and calculated data which have been obtained by the study of chitosan films before and after heat treatment. It has been established that the increase of temperature (from 293 to $318 \mathrm{~K}$ ) and time of drying (from 10 to $72 \mathrm{~h}$ ) of the films had almost no effect on degree of conversion of the amino in amide groups for samples of chitosan films S-form. It means that GlcNAc-fragments of chitin are not formed in the structure of chitosan after films drying. In contrast, the number of amide groups is increased at high temperatures (388 K) in samples of chitosan films S-form-T. This fact indicates that the amidation reaction takes place (Fig. 3).

Acetylamide groups are less active compared with the amino groups and this was proved by quantum chemistry methods in previous studies [31, 32]. Acetylamide groups form a large number of intermo- lecular hydrogen bonds, which leads to a decrease in the affinity of films to water and, consequently, decreases the solubility of films.

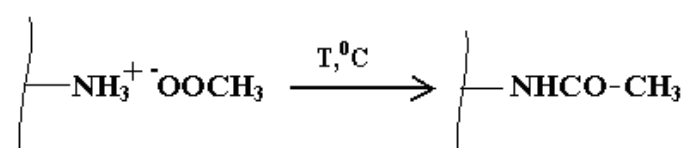

Fig. 3. Scheme of the chitosan amidation reaction

It was found that chitosan film ( $\mathrm{S}$-form and $\mathrm{H}$ form) which were obtained by dry method and dried at 293-318 K unlimitedly swell and fully dissolve at all $\mathrm{pH}$ values after $30-40 \mathrm{~min}$.

The results that characterize the equilibrium degree of swelling and the degree of dissolution of chitosan films after heat treatment ( $\mathrm{S}$-form- $\mathrm{T}$ and $\mathrm{H}$-form- $\mathrm{T}$ ) are presented in Table 2. As can be seen from the experimental data, the chitosan films limitedly swell and do not dissolve completely after being subjected to high temperature $(388 \mathrm{~K})$. This fact can be explained by a decrease in content of amino groups and turning them into amide under high temperature (Table 1), which reduces the total charge along chitosan molecules, which in turn helps to reduce swelling and solubility of films.

As can be seen from Table 2, the $\mathrm{pH}$ values of the solutions in which swelling takes place affect the value of the swelling degree and solubility of chitosan films. At $\mathrm{pH}=1.1$ there is a partial dissolution of chitosan for both $\mathrm{S}$-form- $\mathrm{T}$ and for $\mathrm{H}$-form- $\mathrm{T}$ films that leads to intense swelling of the polymer and increase of the sol-fraction. It was found that chitosan film is more stable at $\mathrm{pH}=6.86$ where a decrease in the equilibrium degree of swelling and sol-fraction is observed. In our opinion, this is due to the decrease in the degree of deacetylation of chitosan, i.e. reduction of amino groups in the films. Therefore, at $\mathrm{pH}=6.86$ the total charge decreases along macromolecules of chitosan, and accordingly, hydration of chitosan molecules becomes smaller.

Thus, the structure of the polymer after heat treatment becomes more stable, which is a positive result and enables the use of chitosan films in solutions with unstable $\mathrm{pH}$. The results agree well with the data obtained by other authors [33-35].

Chitosan film was analyzed by infrared spectroscopy before and after heat treatment. Under the influence of temperature in the infrared spectra of chitosan films (S-form) the decrease in the intensity of the absorption bands Amide I $\left(1633,1630 \mathrm{~cm}^{-1}\right)$ and appearance of intense absorption bands Amide II $\left(1550 \mathrm{~cm}^{-1}\right)$ (Figs. 4, 5) are observed. 
Table 1

Conditions of drying and parameters of the chitosan films

\begin{tabular}{|c|c|c|c|c|c|c|c|c|c|}
\hline \multicolumn{2}{|c|}{ Conditions of chitosan films drying } & \multicolumn{3}{|c|}{ Composition of chitosan films (S-form) } & \multicolumn{3}{c|}{ Composition of chitosan films (S-form-T*) } \\
\hline$T, \mathrm{~K}$ & $\tau, \mathrm{h}$ & $W(N), \%$ & $\varphi_{\mathrm{NH}_{2}}$ & $\varphi_{\mathrm{NHCOCH}_{3}} * *$ & $D C_{\mathrm{NH}_{2}}$ & $W(N), \%$ & $\varphi_{\mathrm{NH}_{2}}$ & $\varphi_{\mathrm{NHCOCH}_{3}} * *$ & $D C_{\mathrm{NH}_{2}}$ \\
\hline 293 & 72 & 7.3 & 0.87 & 0.03 & 0.036 & 5.08 & 0.64 & 0.21 & 0.24 \\
\hline 303 & 20 & 7.4 & 0.88 & 0.04 & 0.048 & 3.97 & 0.51 & 0.33 & 0.39 \\
\hline 318 & 15 & 7.9 & 0.93 & 0.09 & 0.107 & 4.2 & 0.54 & 0.31 & 0.36 \\
\hline 318 & 10 & 7.8 & 0.92 & 0.08 & 0.095 & 4.3 & 0.55 & 0.29 & 0.35 \\
\hline
\end{tabular}

Notes: * heat treatment was performed at $388 \mathrm{~K}$ for $3 \mathrm{~h}$; ** increase of $\varphi_{\mathrm{NHCOCH}_{3}}$ from baseline of chitosan

Table 2

The equilibrium degree of swelling and solubility of chitosan films after heat treatment*

\begin{tabular}{|c|c|c|c|c|}
\hline \multirow{2}{*}{$\mathrm{pH}$} & \multicolumn{2}{|c|}{ Equilibrium degree of swelling $\left(\alpha_{e q}\right), \%$} & \multicolumn{2}{|c|}{ Dissolution, \% } \\
\cline { 2 - 5 } & S-form-T & H-form-T & S-form-T & H-form-T \\
\hline 1.1 & 1120 & 1450 & 25.2 & 34.8 \\
\hline 5.5 & 680 & 950 & 17.1 & 24.6 \\
\hline 6.86 & 520 & 890 & 16.0 & 19.5 \\
\hline
\end{tabular}

Note:* heat treatment was performed at $388 \mathrm{~K}$ for $3 \mathrm{~h}$

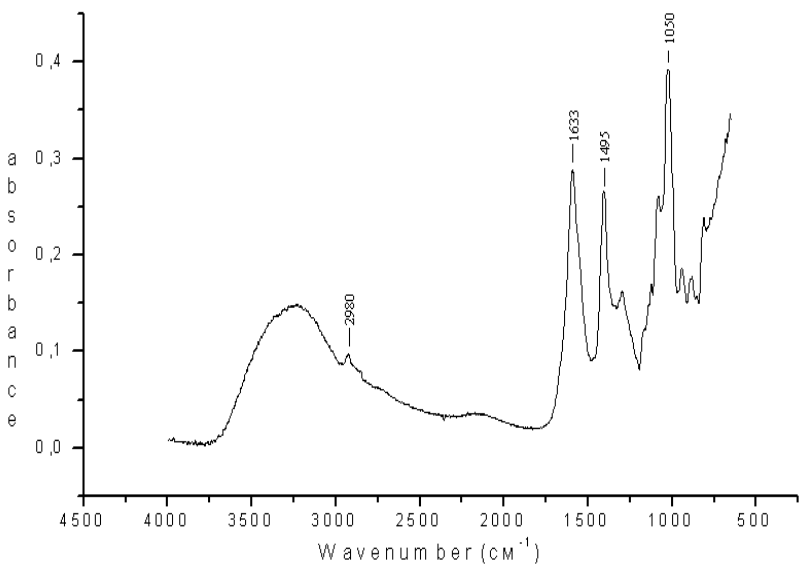

Fig. 4. IR spectrum of chitosan film in the S-form before heat treatment

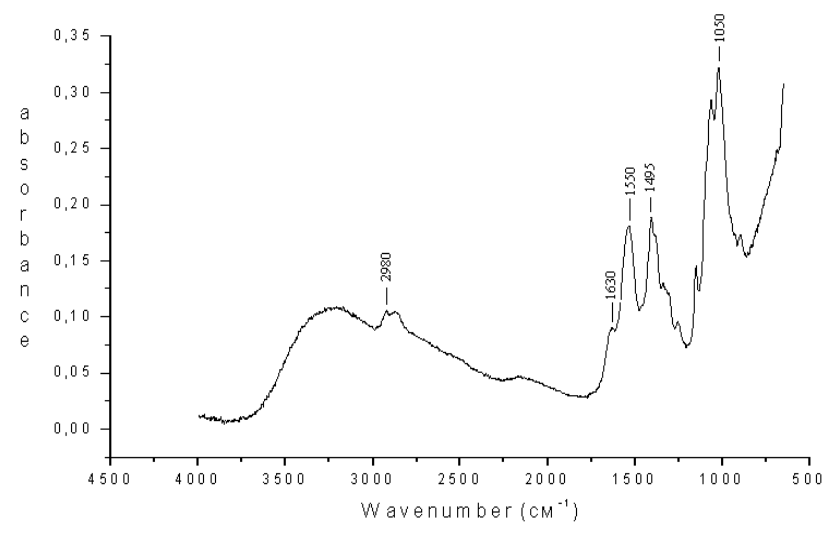

Fig. 6. IR spectrum of chitosan film in the H-form before heat treatment

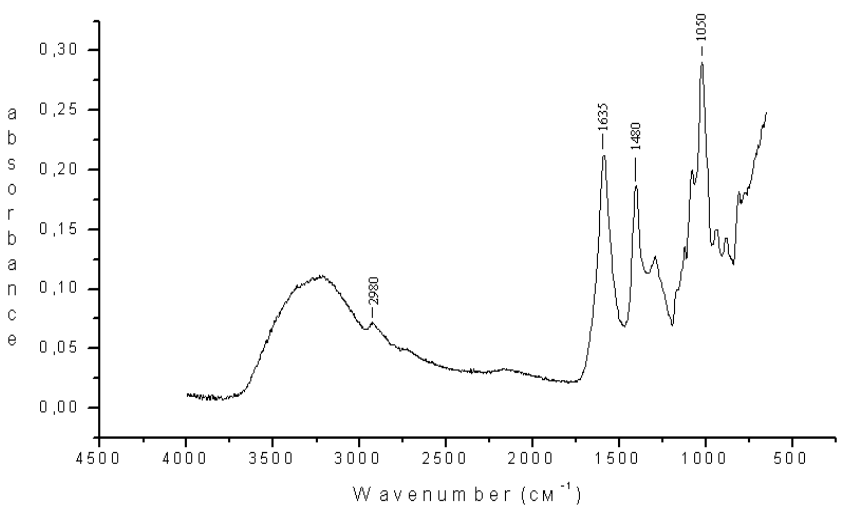

Fig. 5. IR spectrum of chitosan film in the S-form after heat treatment

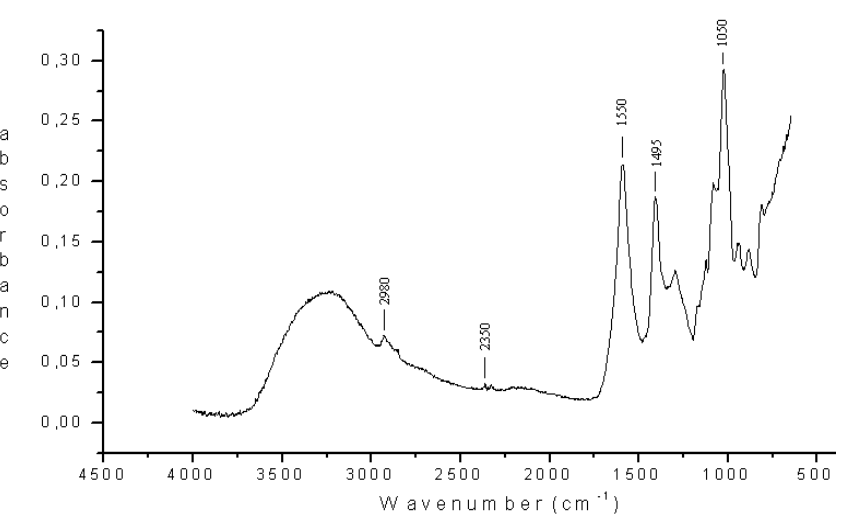

Fig. 7. IR spectrum of chitosan film in the H-form after heat treatment 


\section{Conclusions}

It was proven that increasing the drying temperature of films to $318 \mathrm{~K}$ and drying time up to $72 \mathrm{~h}$ does not influence the degree of conversion of the amino and acetylamide groups in the samples of chitosan films.

It was found that the chitosan films ( $\mathrm{S}$-form and $\mathrm{H}$ form) obtained by dry method and dried at 293-318 K unlimitedly swell and fully dissolve at all $\mathrm{pH}$ values.

It was established that under the influence of temperature $(388 \mathrm{~K})$ amidation reaction in the structure of chitosan films, namely, converting of amino $\left(-\mathrm{NH}_{2}\right)$ to acetylamide group $\left(-\mathrm{NH}-\mathrm{C}(\mathrm{O})-\mathrm{CH}_{3}\right)$ takes place. Formation of new chitin fragments occurs, which contributes to reduction of films affinity to water, and thereby reduces films solubility.

It was found that chitosan film is more stable at $\mathrm{pH}=6.86$, where the decrease in the equilibrium degree of swelling and quantity of sol-fraction is observed. In our opinion, this is due to the decrease in the degree of deacetylation of chitosan, which, consequently, decreases the total charge along chitosan macromolecules, thereby reducing the chitosan molecules hydration.

Chitosan films were analyzed by IR spectroscopy, which confirmed the structural changes in the molecule of chitosan at a high temperature. These changes occur due to amidation reaction.

Thus, the structure of the polymer after heat treatment becomes more stable, which is a positive result and enables the use of a film of chitosan in solutions with unstable $\mathrm{pH}$.

The thermal modification process of the chitosan films presented in our work may find practical use for adjusting the degree of swelling and dissolution of the films depending on their application.

\section{References}

[1] Muzzarelli R.: Chitin. Pergamon Press Ltd., Oxford 1977.

[2] Younes I., Rinaudo M.: Mar. Drugs, 2015, 13, 1133. https://doi.org/10.3390/md13031133

[3] Roberts G.: Chitin Chemistry. Macmillan Press Ltd., London

1992. https://doi.org/10.1007/978-1-349-11545-7

[4] Chen R., Lin H., Yang M.: Carbohydr. Polym., 1994, 24, 41. https://doi.org/10.1016/0144-8617(94)90115-5

[5] Chen R., Hua H.: J. Appl. Polym. Sci., 1996, 61, 749. https://doi.org/10.1002/(SICI)1097-

4628(19960801)61:5<749::AID-APP5>3.0.CO;2-O

[6] Gacen J., Gacen I.: Bol. Intexter., 1996, 110, 67.

[7] Bhanoori M., Venkateswerlu G.: Biochim. Biophys. Acta., 2000, 1519, 21. https://doi.org/10.1016/S0304-4165(00)00090-8

[8] Singh D., Ray A.: Carbohyd. Polym., 1998, 36, 251. https://doi.org/10.1016/S0144-8617(97)00260-9

[9] Begin A., Van Calsteren M.R.: Carbohyd. Polym., 1999, 26, 63.

[10] Hirano S., Tokura S. Proc. of the Second Int. Conf. on Chitin and Chitosan, Japan, Sapporo 1982, 254.

[11] Butler B., Vergano P., Testin R.. et al.: J. Food Sci., 1996, 61, 953. https://doi.org/10.1111/j.1365-2621.1996.tb10909.x

[12] Chen R., Hwa H.: Carbohyd. Polym., 1996, 29, 353. https://doi.org/10.1016/0144-8617(96)00005-7
[13] Singh D., Ray A.: Carbohyd. Polym., 1998, 36, 251. https://doi.org/10.1016/S0144-8617(97)00260-9

[14] Lim L., Wan L.: Drug Dev. Ind. Pharm., 1995, 21, 839. https://doi.org/10.3109/03639049509026648

[15] Bhuvaneshwari S., Sruthi D., Sivasubramanian V. et al.: Int. J. Eng. Res. Appl., 2011, 1, 292.

[16] El-hefian E., Nasef M., Yahaya A., Khan R.: Aust. J. Basic Appl. Sci., 2011, 5, 670.

[17] Yue Dong Yang, Jiu Gao Yu, Yong Guo Zhou, Pei Guo L.: Chinese Chem. Lett., 2005, 16, 991.

[18] Qing-lei Qi, Qiang Li, Jian-wei Lu et al.: Chinese J. Polym. Sci., 2009, 27, 387. https://doi.org/10.1142/S0256767909004047

[19] Kawada J, Yui T, Okuyama K, Ogawa K.: Biosci. Biotechnol. Biochem., 2001, 65, 2542. https://doi.org/10.1271/bbb.65.2542

[20] Ogawa K., Yui T., Miya M.: Biosci. Biotechnol. Biochem., 1992, 56, 858. https://doi.org/10.1271/bbb.56.858

[21] Yamamoto A., Kawada J., Yui T., Ogawa K.: Biosci. Biotechnol. Biochem., 1997, 61, 1230.

https://doi.org/10.1271/bbb.61.1230

[22] Demarger-Andre S., Domard A.: Carbohyd. Polym., 1994, 23, 211. https://doi.org/10.1016/0144-8617(94)90104-X

[23] Lim L., Lucy S.: Drug Develop. Ind. Farm., 2001, 2, 143.

[24] Kim J.H., Kim J.Y., Lee Y.M., Kim K.Y.: J. Appl. Polym. Sci., 1992, 45, 1711.

[25] Stoljarenko G., Solodovnik T., Kurilenko Ju., Iegorova O.: Pat. Ukr. 79581, Publ. Apr. 25, 2013.

[26] Stoljarenko G., Solodovnik T., Kurilenko Ju., Iegorova O.: Pat. Ukr. 89696, Publ. Apr. 25, 2014.

[27] Samuels R.: J. Polym. Sci., 1981, 19, 1081.

[28] Arzamascev O., Abdullin V., ArtemenkoS.: Khim. Volokna, 2008, 6, 21.

[29] Zotkin M., Vihoreva G., Smotrina T., Derbenev M.: Khim. Volokna, 2004, 1, 14.

[30] Kim S., Rajapakse N.: Carbohyd. Polym., 2005, 62, 357. https://doi.org/10.1016/j.carbpol.2005.08.012

[31] Barakov R., Solodovnik T., Minaev B. et al.: Visnyk Cherkask. Univ. Ser. Khim. Nauky, 2010, 174, 80.

[32] Solodovnik T.: [in:] Loureiro J., Kartel M. (Eds.), Combined and Hybrid Adsorbents. Springer, Netherlands 2006, 275-280. https://doi.org/10.1007/1-4020-5172-7_33

[33] Buzinova D., Shipovskaja A.: Izv. Saratovskogo Univ. Ser. Khimiia. Biologiia. Ekologiia, 2008, 8, 42.

[34] Kulish E., Rezjapova N., Mudarisova R.: Vesnik Bashkirskogo Univ., 2009, 14, 377.

[35] Kulish E., Chernova V., Volodina V., Kolesov S.: Vesnik Bashkirskogo Univ., 2008, 13, 23.

Received: February 04, 2016 / Revised: October 17, 2016 /

Accepted: J anuary 12, 2017

\section{ДОСЛІДЖЕННЯ ВПЛИВУ ТЕРМІЧНОГО ОБРОБЛЕННЯ НА СТРУКТУРУ ТА РОЗЧИННІСТЬ ХІТОЗАНОВИХ ПЛІВОК}

Анотація. Одержані хітозанові плівки в сольовій формі та у формі поліоснови. Плівки були виготовлені сухим способом формування. Вперше для виготовлення плівок використовували хітозан з відходів міцеліальної біомаси гриба Аspergillus Niger. Досліджено вплив термічного оброблення на структуру та розчинність плівок. Доведено, що при термообробленні хітозанових плівок відбувається реакція амідування, яка, в свою чергу, сприяє упорядкуванню структури та зменшенню розчинності плівок.

Ключові слова: термічна модифікачія, хітозан, плівка, розчинність, набухання. 